\title{
Anabases
}

ANABASES Traditions et réceptions de l'Antiquité

$23 \mid 2016$

Varia

\section{Les grandes universités américaines}

\section{Franz Cumont}

\section{OpenEdition}

Journals

Édition électronique

URL : http://journals.openedition.org/anabases/5667

DOI : 10.4000/anabases.5667

ISSN : 2256-9421

\section{Éditeur}

E.R.A.S.M.E.

\section{Édition imprimée}

Date de publication : 2 mai 2016

Pagination : 227-269

ISSN : 1774-4296

\section{Référence électronique}

Franz Cumont, «Les grandes universités américaines », Anabases [En ligne], 23 | 2016, mis en ligne le 02 mai 2019, consulté le 23 octobre 2019. URL : http://journals.openedition.org/anabases/5667 ; DOI : 10.4000/anabases.5667

Ce document a été généré automatiquement le 23 octobre 2019

(c) Anabases 


\section{Les grandes universités américaines}

Franz Cumont

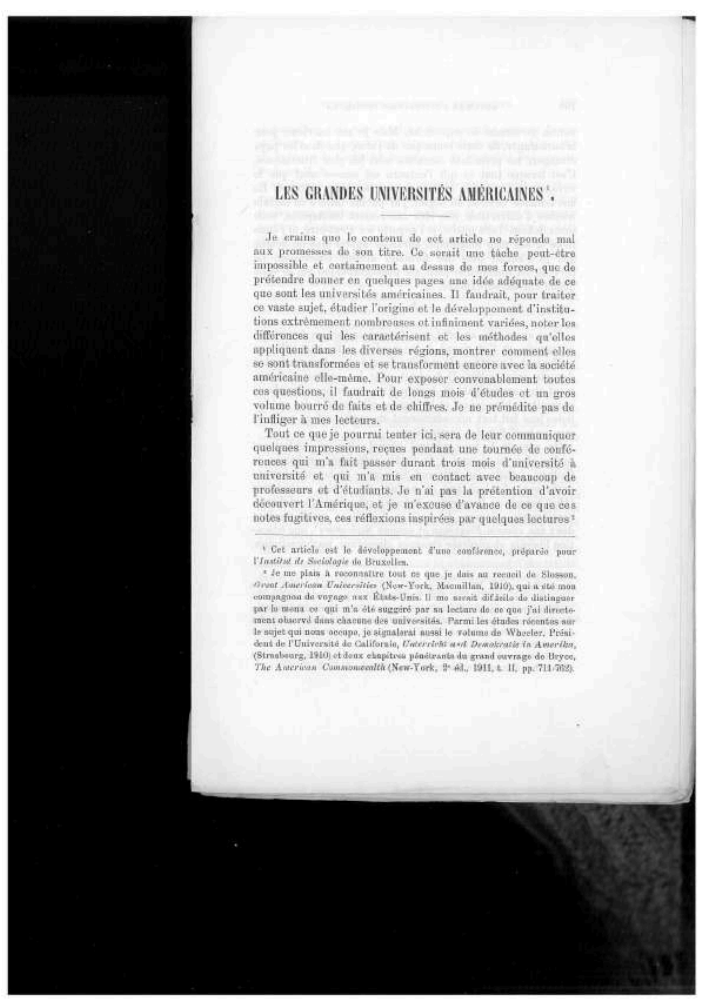



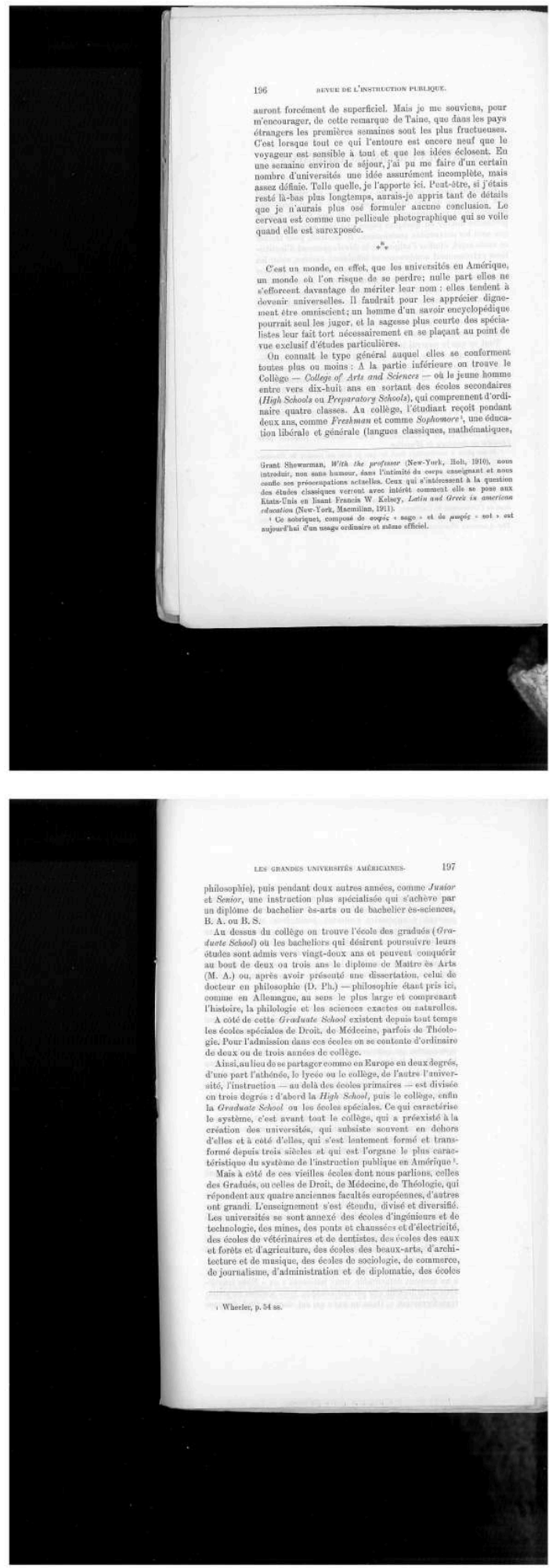

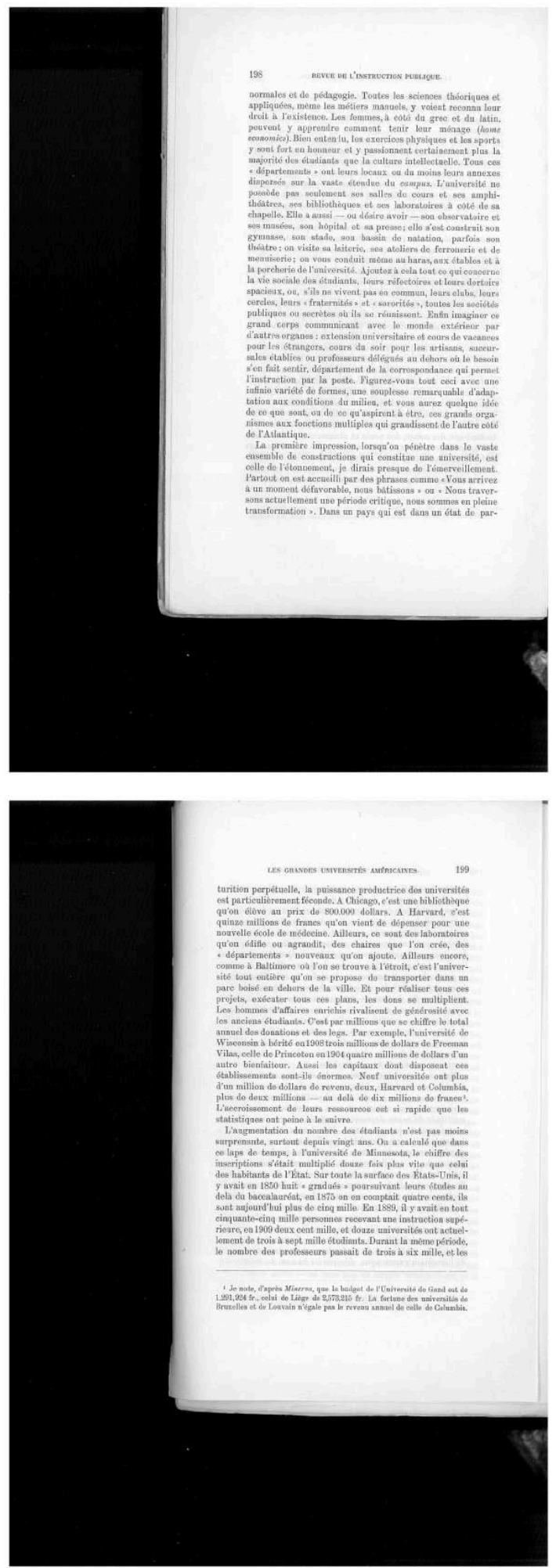

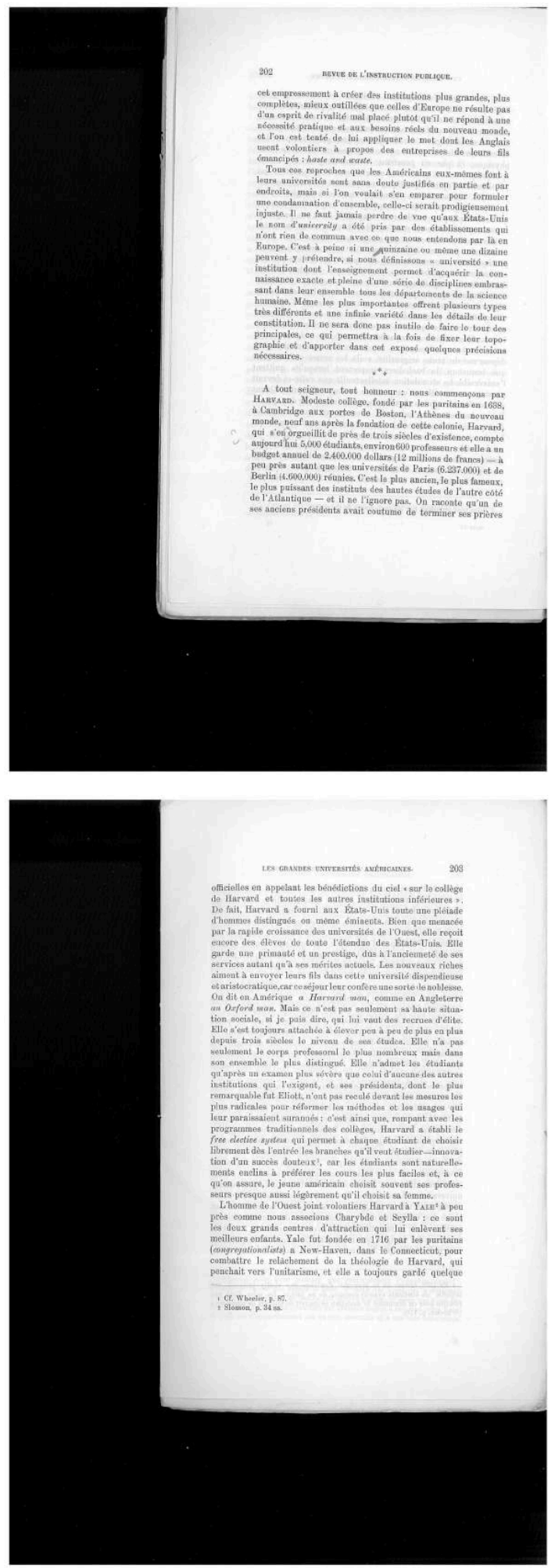

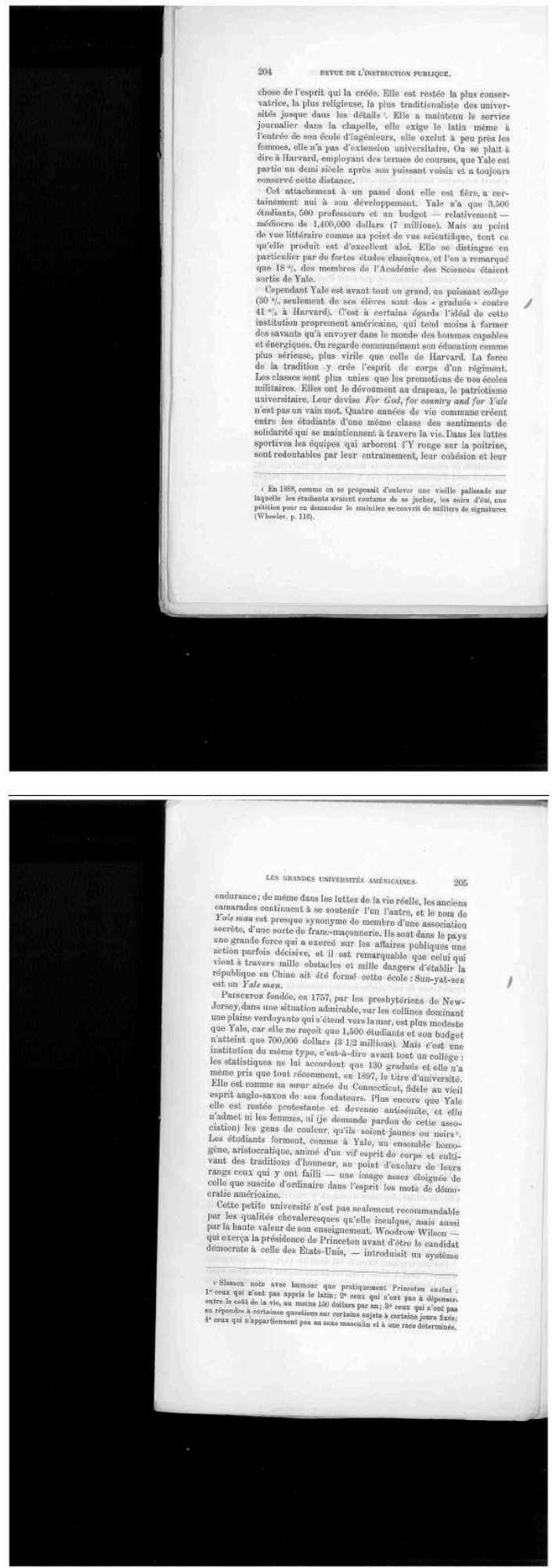

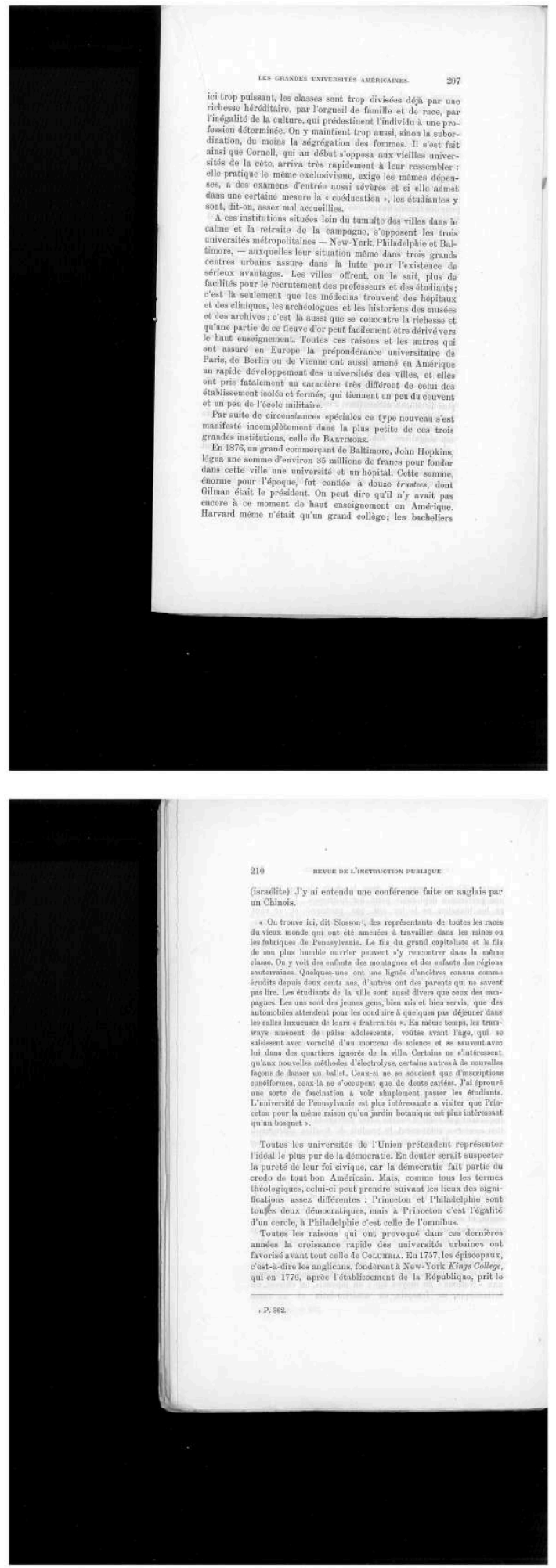

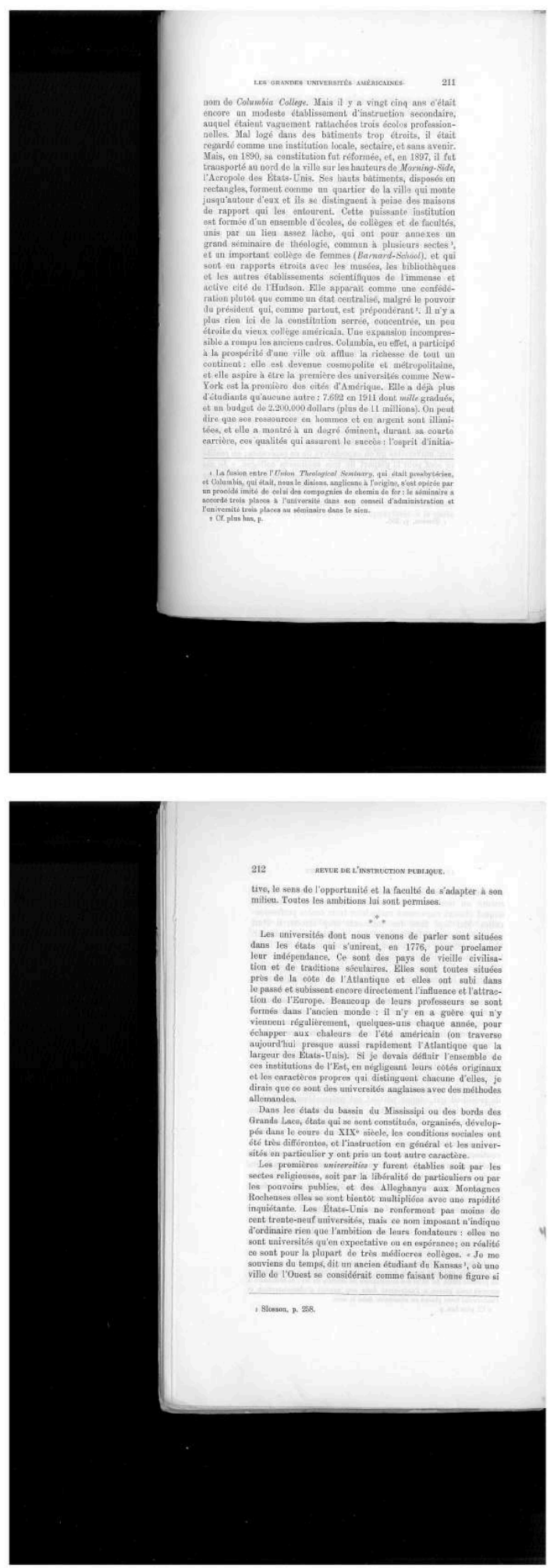

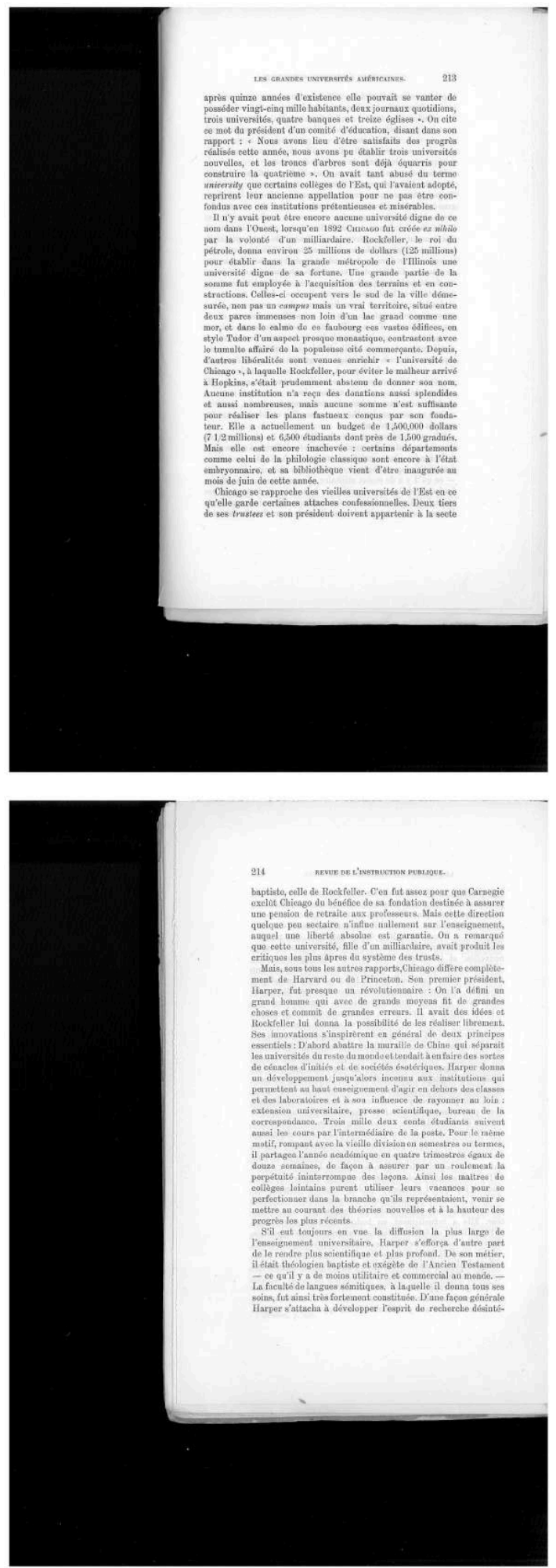

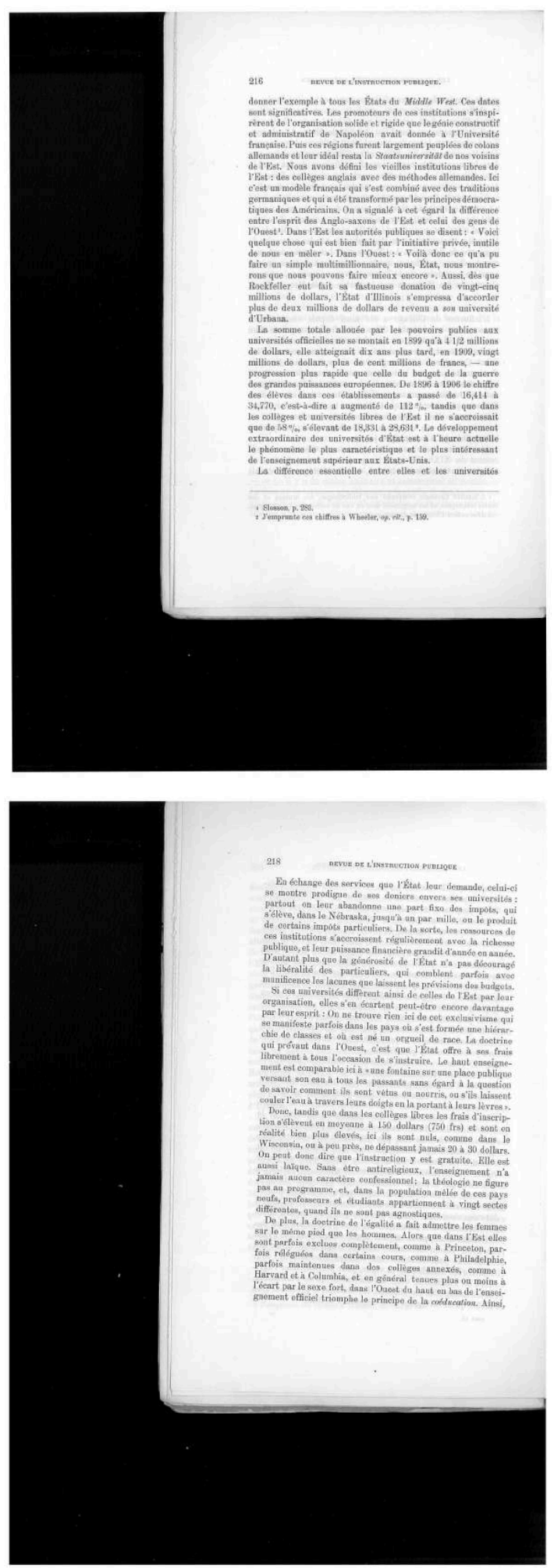

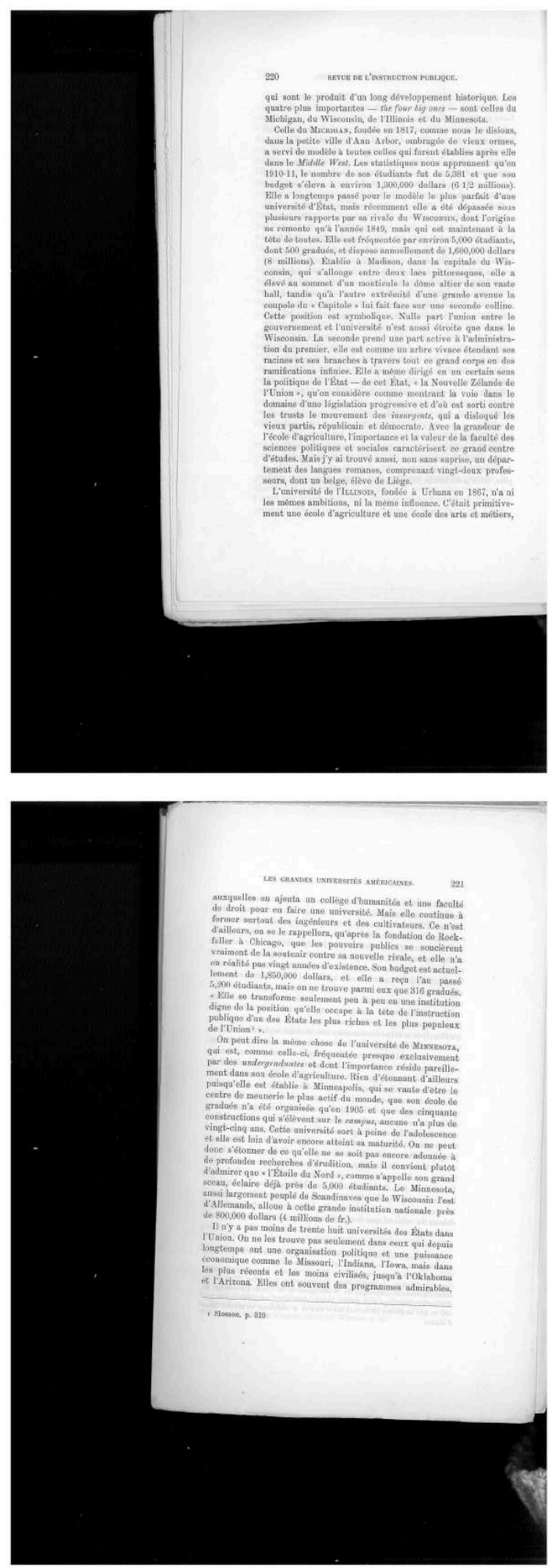

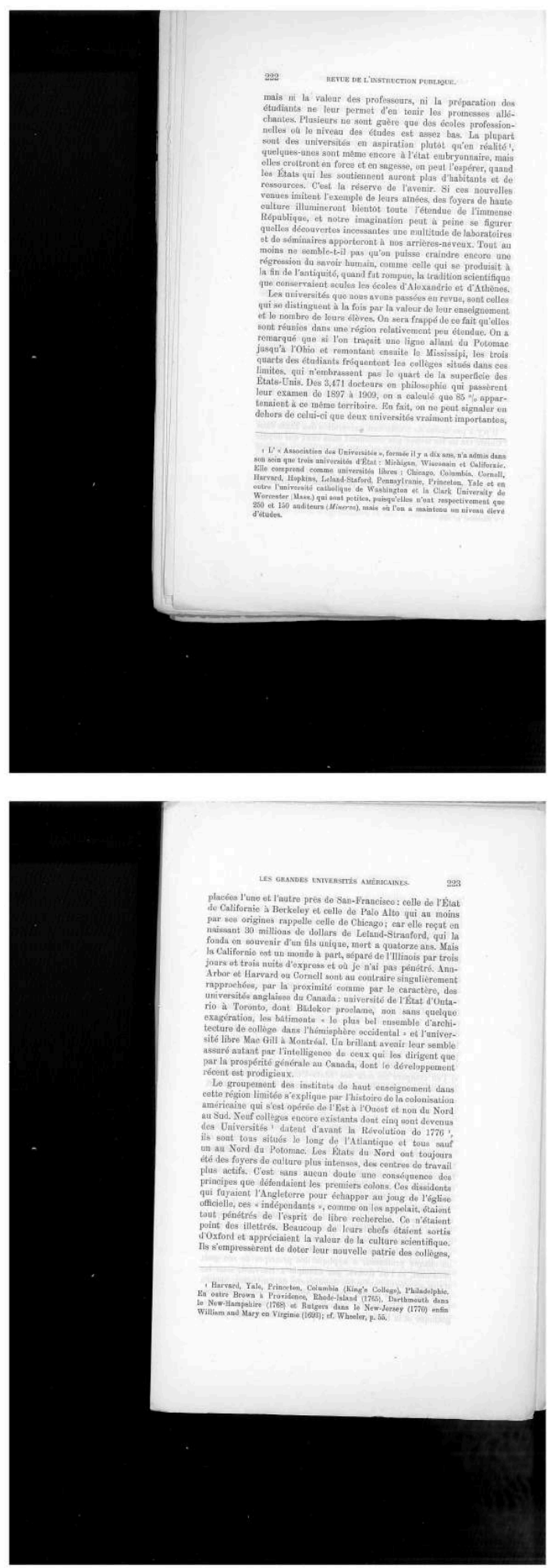

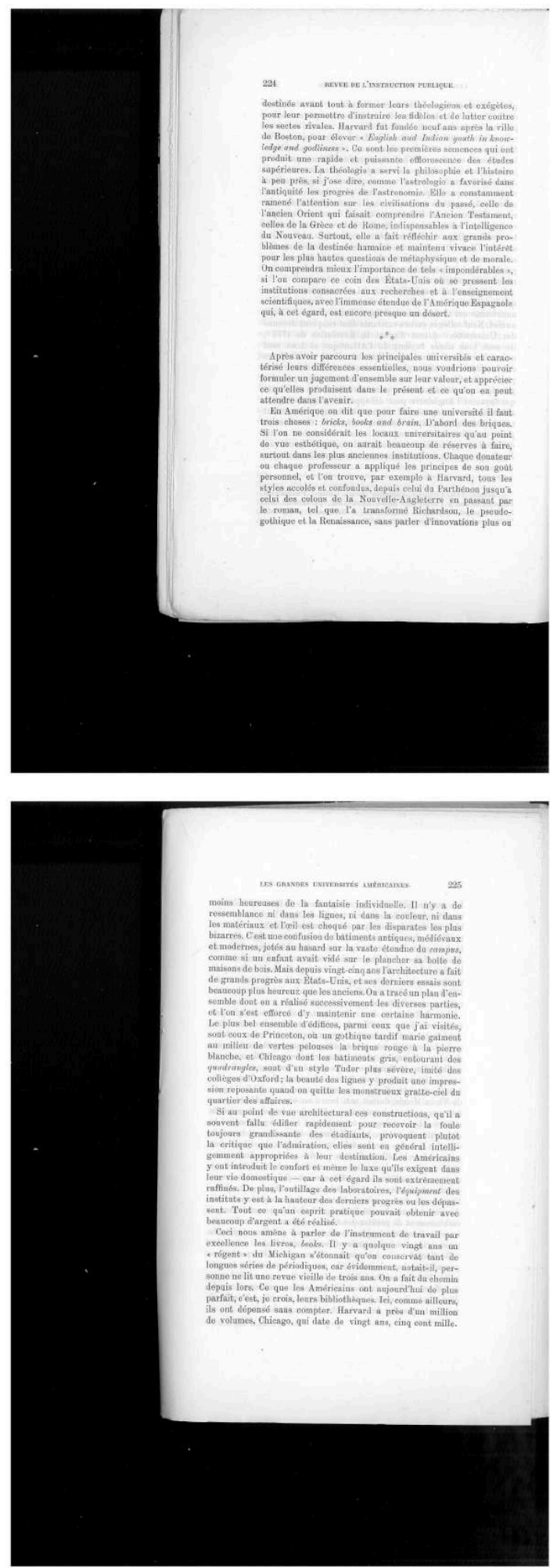

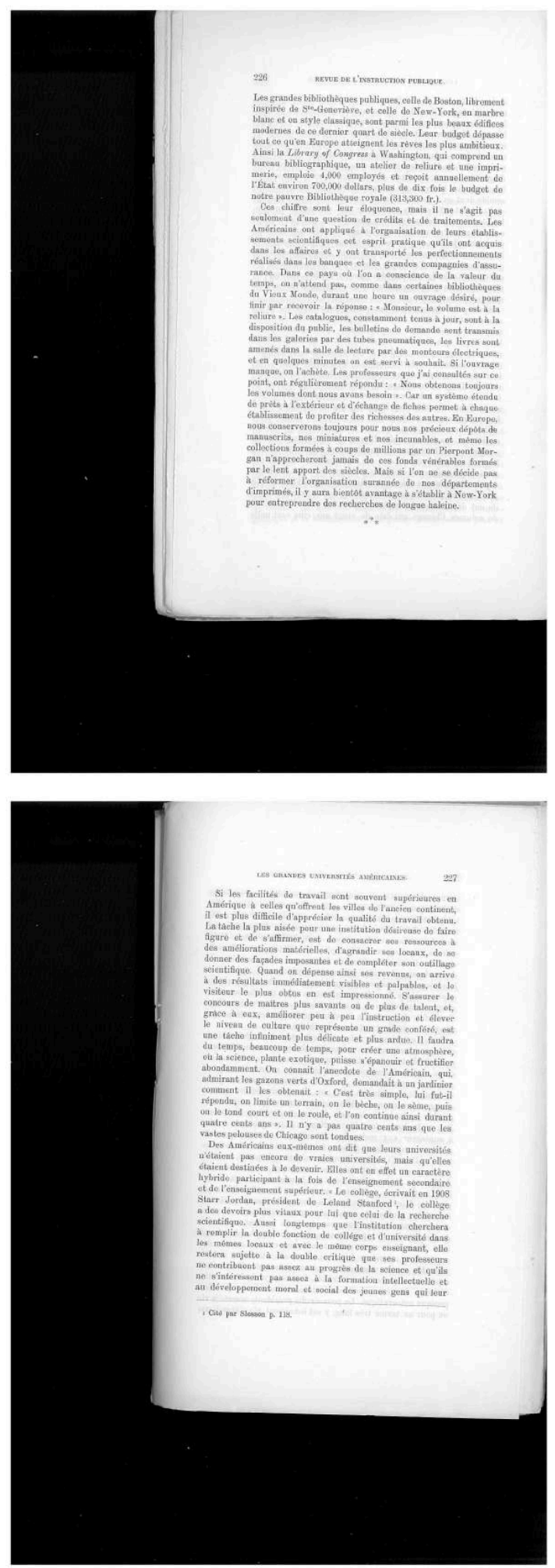

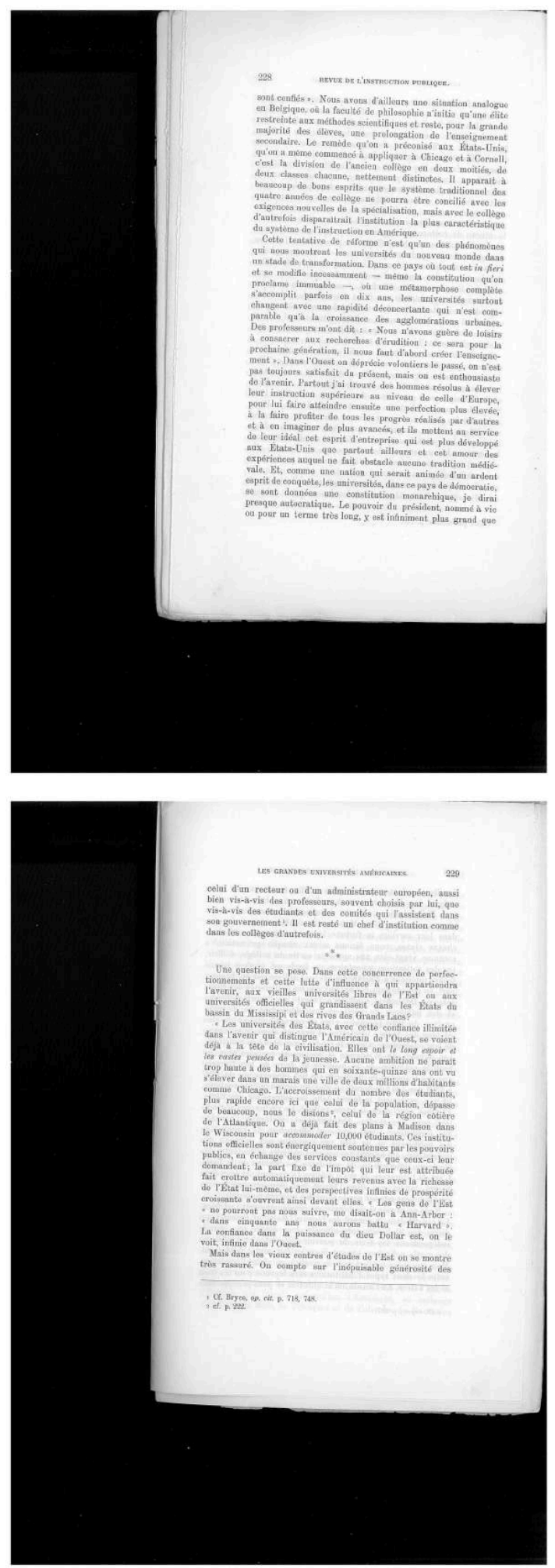

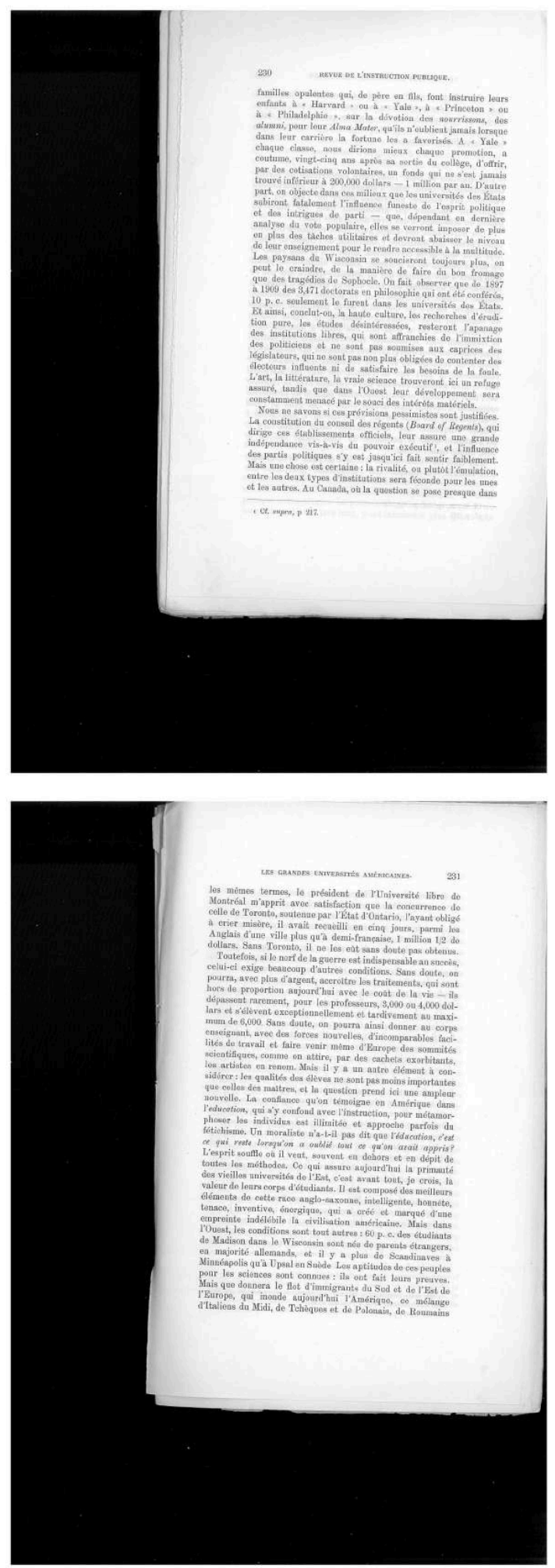

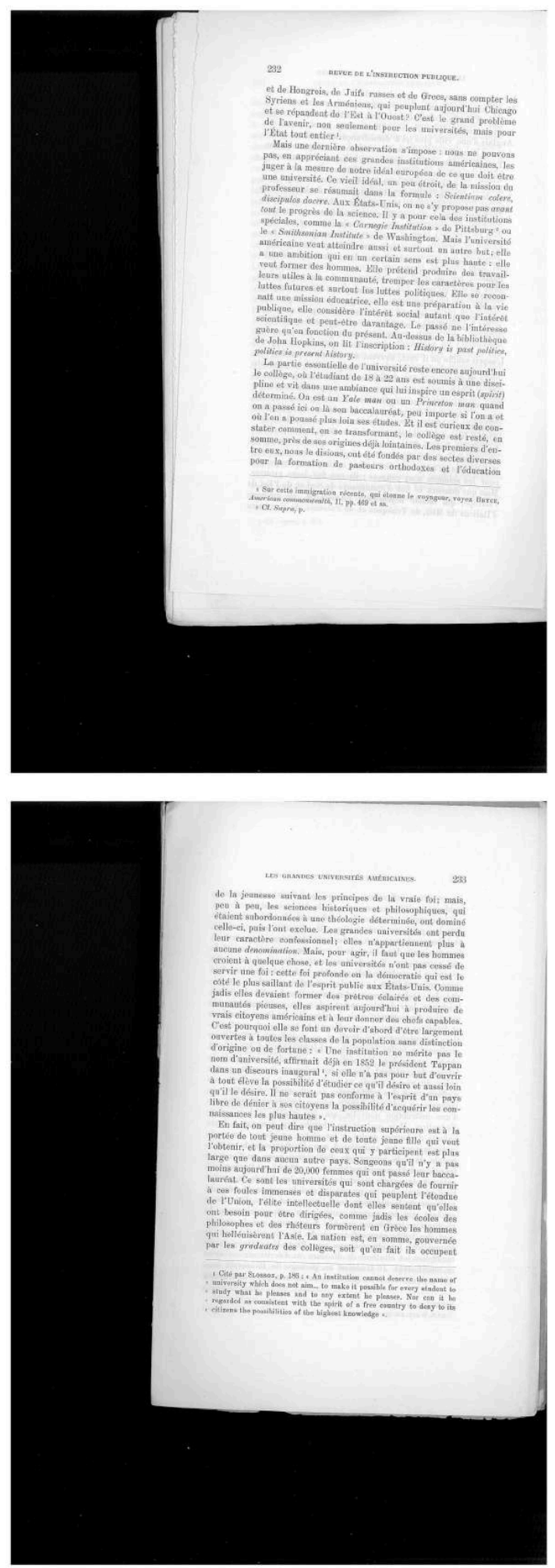

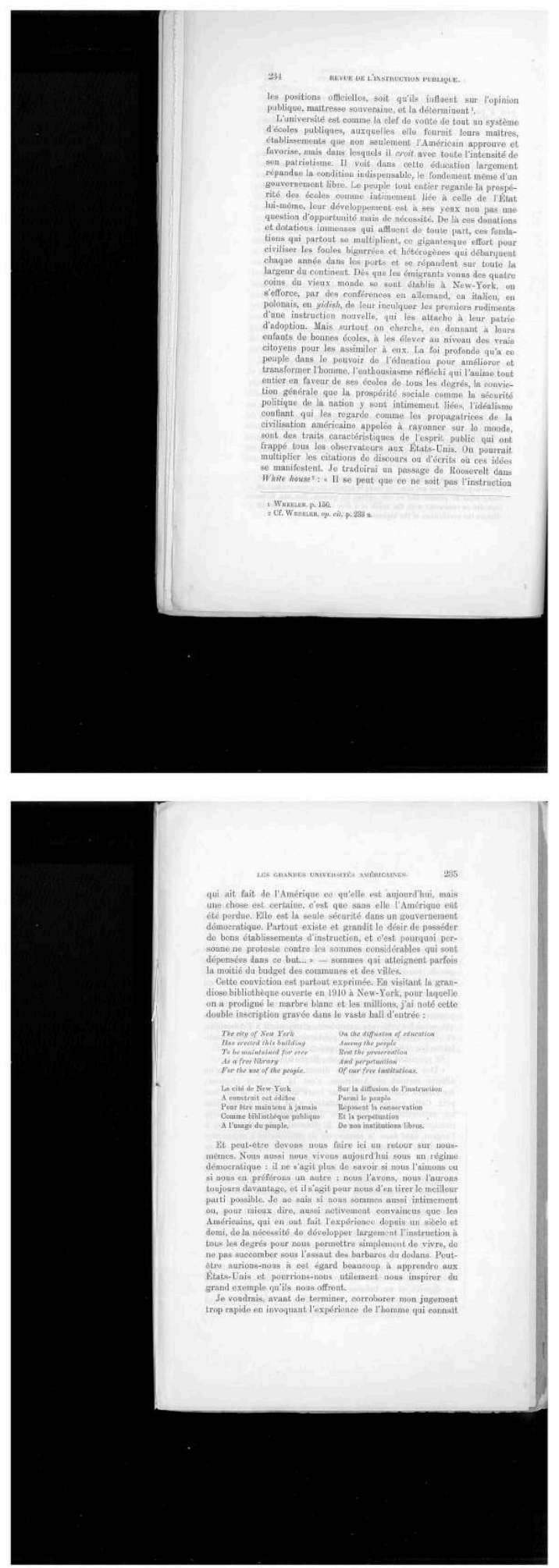

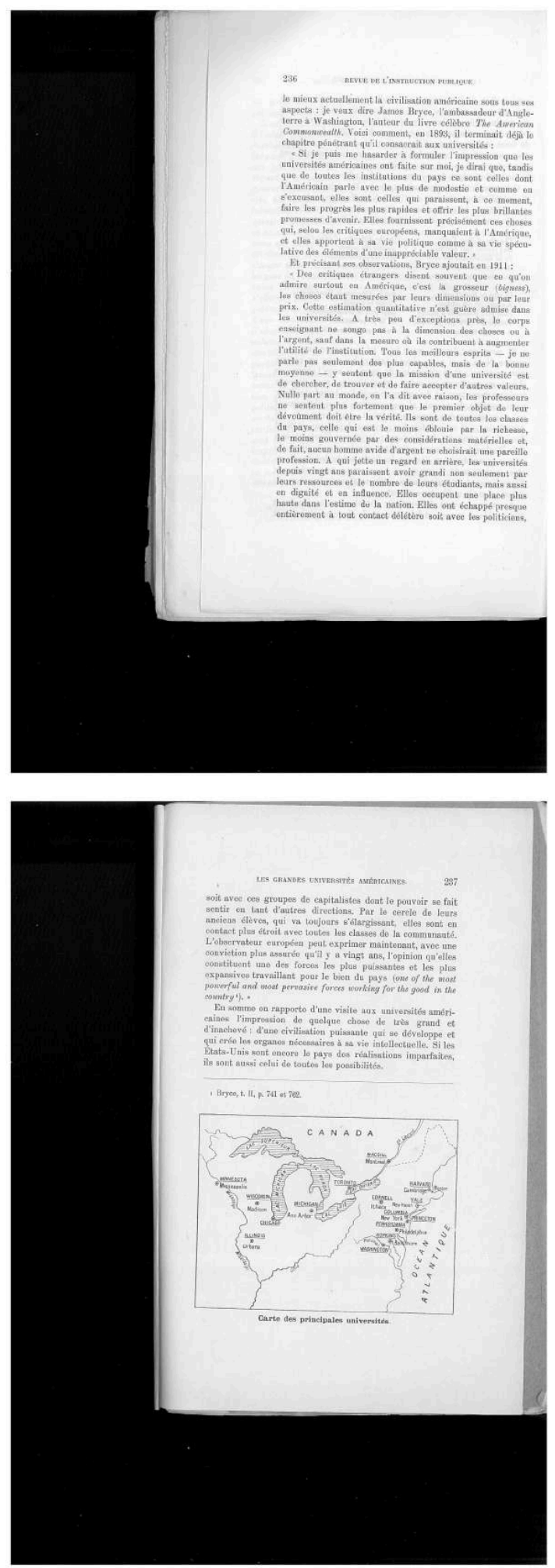